\title{
PERMACULTURE ZONE PLANNING USING THE TRIANGULAR METHOD
}

Professional paper / Stručni rad

Srđan Babac

(Received: 11 November 2018; accepted: 11 December 2018)

University of Zagreb, Faculty of Agriculture, Student

Damir Belić

University of Zagreb, Faculty of Mechanical Engineering and Naval Architecture, Assistant

Corresponding author: dbelic@fsb.hr

\begin{abstract}
Permaculture is a multifaceted, integrated, and ecologically harmonious method of designing human centered landscapes. One of the key elements in planning permaculture systems is zone planning. In this method, the locations of system elements are determined by two factors: (1) the number of times a human wants to visit a plant, animal, or structure, which corresponds to using the element; (2) the number of times a plant, animal, or structure should be visited by a human, which corresponds to servicing the element. These criteria for zone planning are fundamentally the same as the ones used for production system planning. In permaculture system planning, the criterion is related to interactions between humans and environmental elements, while in production systems, it is related to the number of interactions between system elements, such as machines or structure objects. The goal of planning in production systems is also the same as in permaculture, i.e., the determination of the most favorable spatial arrangement of the system elements. The goal of this study is to present a possible application of one of the production planning optimization methods for permaculture, i.e., zone planning. The optimization method-the Bloch-Schmigalla triangular method is based on the material flow according to the minimum transport distance criterion.
\end{abstract}

Keywords: Permaculture; zone planning; production planning; material flow; triangular method

\section{PROJEKTIRANJE ZONA PERMAKULTURE METODOM TROKUTA}

Sažetak: Permakultura je višeslojna, integralna i ekološki skladna metoda oblikovanja krajolika, kojoj je u središtu čovjek. Jedan od ključnih elemenata u projektiranju permakulturnih sustava jest određivanje zona. Određivanje zona je metoda kojom se određuje lokacija elemenata sustava na temelju dvaju kriterija: (1) koliko puta čovjek treba posjetiti neku biljku, životinju ili građevinu, što se smatra korištenjem elemenata;(2) koliko puta biljka, životinja ili građevina treba biti posjećena od strane čovjeka, što se smatra održavanjem elemenata. Kriteriji određivanja zona su fundamentalno jednaki kriterijima korištenim u projektiranju proizvodnih sustava. U projektiranju permakulturnih sustava kriterij je povezan s interakcijom između čovjeka i elemenata sustava, dok je pri projektiranju proizvodnih sustava kriterij broj interakcija između različith elemenata proizvodnog sustava, kao što su strojevi ili građevinski objekt. Projektiranje proizvodnih sustava ima isti cilj kao i prermakulturno projektiranje, a to je određivanje najpovoljnijeg prostornog rasporeda elemenata sustava. Svrha ovoga rada je prikazati mogućnost primjene jedne od optimizacijskih metoda projektiranja proizvodnih sustava u permakulturi za određivanje permakulturnih zona. Metoda optimizacije - Bloch-Schmigalla metoda trokuta, zasniva se na toku materijala prema kriteriju minimalne transportne udaljenosti.

Ključne riječi: permakultura; određivanje zona; projektiranje proizvodnih sustava; tok materijala; metoda trokuta 


\section{INTRODUCTION}

Permaculture design is a concept that aims at transforming not only agriculture, but also the entire human habitat involving city planning, architecture, development, etc. [1]. Concisely, permaculture ("permanent agriculture" or "permanent culture") is a method for designing agricultural landscapes and sustainable human communities (societies) by simulating or directly utilizing patterns perceived in natural ecosystems. The goal is that the designed system is close to being self-sustainable and harmonious as is a natural ecosystem, and serves human and societal needs. Permaculture is based on 3 core tenets and 12 principles [2] as presented in Figure 1.

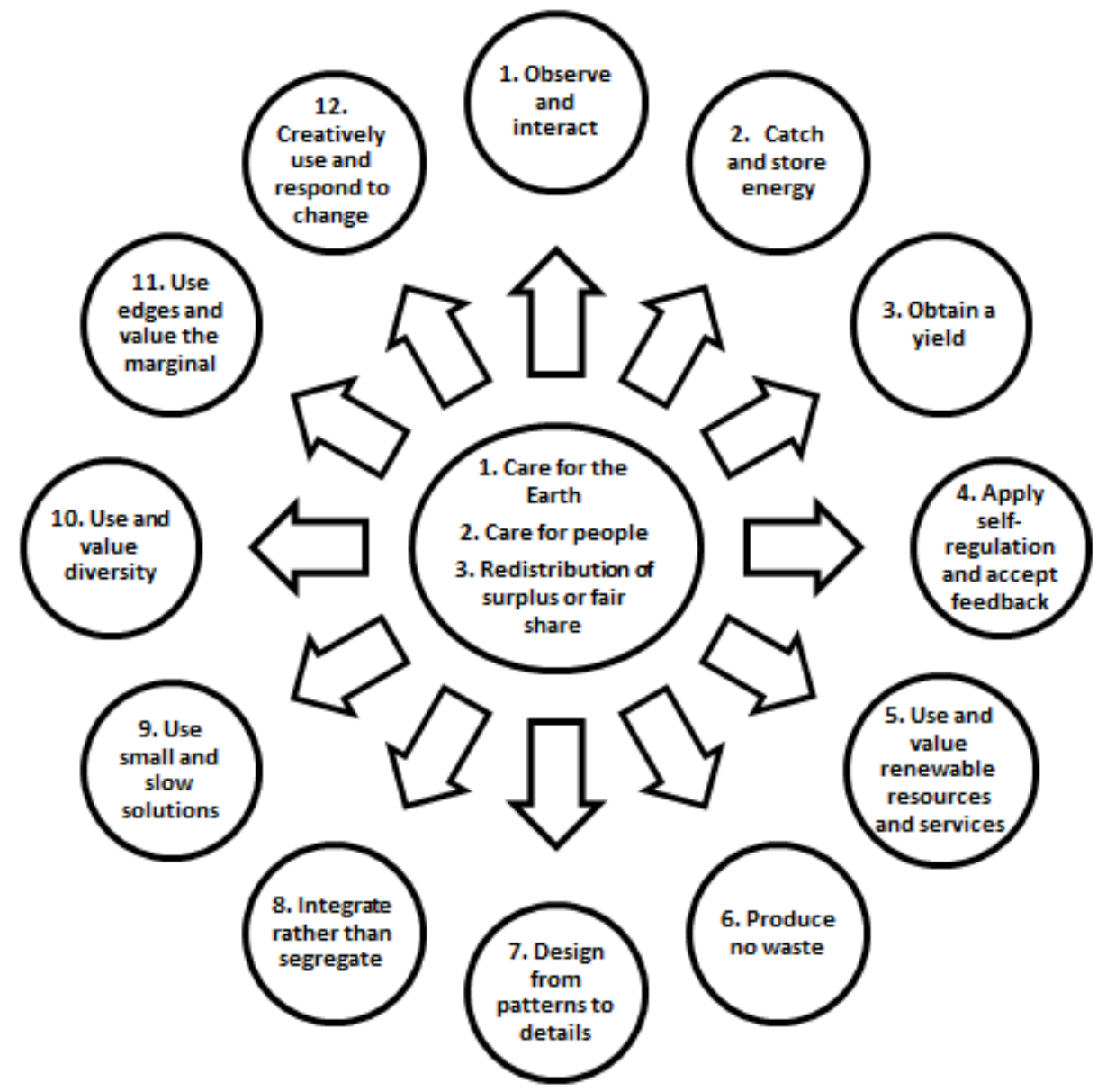

Figure 1 Permaculture core tenets and principles

The fact that ethics and principles of permaculture perfectly comply or coincide with the UN goals for achieving sustainable development in the 21st century shows that permaculture is and will be a big part of the future development of society. One way of describing the way of thinking in permaculture is through the philosophy of Masanobu Fukuoka, one of the "five giant personalities" who inspired the movement of sustainable agricultural and organic farming. The philosophy is to work with, rather than against nature, to act through thoughtful observation rather than thoughtless labor, and to perceive plants and animals in all their functions, rather than treating them as a single-product system [3]. The reason why permaculture is lacking modern scientific methods can be perceived through this philosophy. Permaculture strives to look at natural ecosystems through a holistic approach and then simulating or utilizing observed patterns, whereas, scientific methods have an analytical approach. An analytical approach breaks down natural ecosystems into fragments that are analyzed individually, and subsequently, broad generalizations about the whole system are made. Fukuoka stated that obtaining knowledge and understanding natural systems through in this manner is fragmented and incomplete because no matter how many incomplete fragments are collected, they can never form a complete whole. In other words, humans can never perceive the numerous relationships between an endless chain of cause and effect, which Babac, S, Belić, D 
form a natural phenomenon [4]. The knowledge gained from permaculture is not scientifically derived from system theories, rather, it is axiomatic, practical, and visual knowledge gained through osmosis [1, 2]. Although the knowledge is obtained from nature and there is a lack of scientific methods, Mollison [5] created a method for arranging the elements of the permaculture system, namely the zoning method. This arrangement depends on the quantity of interaction between humans and system elements. Based on the interactions between humans and system elements and between system elements themselves, Mollison [5] divided the system into subsystems called zones. The criteria were derived from nature with the goal of making a system that serves human or community needs in an efficient and sustainable manner, but the method lacks an algorithm that can provide a firm set of rules for the arrangement of the system elements.

Production system planning is a special engineering activity that integrates different technical and nontechnical knowledge and activities for efficient realization and operation of the production system. Unlike permaculture planning, the activities of production system planning use methods that contain algorithms with a firm set of rules to create an optimal layout of the system elements. Mollison [5] took the first step in defining an arrangement for elements and gave the criterion for the division of elements into zones, which can be the first step in the algorithmization of the method.

The main task in every production planning process is creating an optimized facility layout. The planning processes are structured and organized according to different methods and strategies that split the whole process into multiple steps. One of the steps is the creation of a facility layout with an optimized material flow [6]. In literature, the problem of creating a valid material flow system is called a facility layout problem (FLP), and it can be described mathematically by the following formula [7]:

$T_{T}=\sum_{k=1}^{n} \sum_{j=1}^{n} b_{k j} \times s_{k j} \times t_{k j} \rightarrow \min ; k, j=1,2, \ldots, n$

where

$n$ : number of system elements

$T_{T:}$ total transport cost

$b_{k j}$ : material flow intensity between system elements $k$ and $j$

Skj: distance between system elements $k$ and $j$

$t_{k j}$ : transport cost between system elements $k$ and $j$.

FLPs have a major impact on manufacturing costs, lead time, and productivity. A good arrangement of elements contributes significantly to the overall efficiency and reduction of operating costs. Because layout problems are usually complex and they have to deal with various considerations, they are generally considered as NP-hard problems [8]. Although this problem is classified as NP-hard, which requires a heuristic approach, some authors attempt to solve it optimally, as presented by Driara et al. [9], using various branch and bound algorithms $[10,11]$.

Because exact approaches are not suitable for large size problems, numerous researchers have developed heuristic and metaheuristic methods for solving the FLP [9]. Heuristic methods are capable of finding good solutions that can be optimal, but there is no valid technique to determine the deviation of the proposed solutions from the optimal ones. However, a ranking of the proposed solutions from better to worse can be determined by drawing comparisons between them. Heuristic approaches can be based on building or improving procedures [12]. Improving procedures are based on an inifial system layout, random or existing. The basic improvement principle is to replace the location of at least two system elements to improve the existing goal function value. The procedure is repeated long enough to improve the goal function by replacing the location of system elements. Building procedures are based on algorithms for assigning system elements to the planning surface, varying their possible location in relation to the assigned elements, and choosing the position that results in the smallest partial value of the goal function.

Metaheuristic approaches can also be used when addressing the FLP. Some authors use local search methods (tabu search and simulated annealing), evolutionary approaches (genetic and ant colony algorithms), or a hybridization of different metaheuristic algorithms as presented by Driara et al. [9].

In this study, the possible application of a heuristic design method that contains a firm set of rules (algorithm) is presented. The algorithm is required for a faster and an unambiguous element positioning with the goal of a simpler permaculture system design.

Babac, S, Belić, D 


\section{MATERIALS AND METHODS}

The goal of production system optimization methods is to create an optimal layout of the elements based on their interactions, usually by minimizing the transport distance. Currently, there are many methods to minimize the transport distance, such as systematic layout planning, pairwise exchange method, graph based theory, dimensionless block diagram, total closeness rating, Bloch-Schmigalla triangular method, etc. [13].

In this study, the Bloch-Schmigalla triangular method (also known as the modified triangular method or Schmigalla method) is used for permaculture zone planning. The Bloch-Schmigalla triangular method belongs to the heuristic (building) type of layout planning methods. The reason for using a heuristic method is the potential complexity of the FLP problem, which may occur in future practical applications of the method on real permaculture farms with many system elements and complex material flows inside and outside permaculture zones. The goal is to achieve an optimal system layout, and this can be fulfilled by positioning the system elements based on the criteria related to material flow. The first criterion is based on the material flow direction (ensuring a linear material flow direction if possible). The second criterion is the minimization of the transport distance between the system elements, thereby minimizing the total transport intensity [12].

This method was primarily used for planning production systems consisting of interconnected system elements using the model with an unlimited choice of location. Data used for the method implementation was obtained through permaculture literature analysis $[5,14]$. The obtained data was analyzed based on the principles of the Bloch-Schmigalla triangular method. Another reason for using the Bloch-Schmigalla triangular method is that, according to zone planning, this method uses the same criterion for element arrangement (transport distance) and the unlimited choices of locations theoretically comply with the landscape layouts.

The triangular method was developed by Bloch in 1950 [7]. The goal of this method is the arrangement of the system elements based on the criterion of minimum transport distance. The main principles of the triangular method are [12]:

- If a connection (by transport) between two system elements is required, the optimal arrangement is to set them in the terminal positions of a base line

- If a connection between three elements is required, the optimal arrangement is to place them at the vertices of an equilateral triangle

- If there is a fourth element in the system, it can be placed on any of the three possible locations of the adjacent equilateral triangles (which result in minimum transport cost), and so on.

The disadvantage of this method is that it does not indicate which pair of elements is to be placed first in the triangular mesh. Schmigalla improved Bloch's method by adding the goal function of minimum transport output as [15]:

$f_{c}=\sum_{k=1}^{n} \sum_{j=1}^{n} b_{k j} \times s_{k j} \rightarrow \min ; k, j=1,2, \ldots, n$

where

$n$ : number of system elements

$b_{k j:}$ material flow intensity (number of transports) between system elements $k$ and $j$ that

$S_{k j}$ : distance between system elements $k$ and $j$ measured by the number of triangular line segments such

$s_{k j} \geq s ; k, j=1,2, \ldots n$.

The other restriction is that one system element can be placed only at one location and vice versa.

This goal function is similar to the goal function of equation (1) with the difference that the transport cost is neglected. This is because of the assumption that the transport costs will not influence the optimization result as the total transport cost within the system elements is the same (that can be achieved by using the same transport means) [7]. Authors' assumption regarding permaculture is the same, i.e., transport cost within the permaculture farm can be neglected because it is unlikely that humans in the farm will use different transportation means with varying transport costs.

Material flow intensity is expressed by the number of transports between the elements in the planning period (generally one year). The method starts with the determination of the material flow between system elements, which is usually represented by the material flow intensity matrix:

$B^{0}=\left[b_{k j}^{0}\right]_{n} ; k, j=1,2, \ldots, n$. 
Each system element can be either the source or destination of the transport. Hence, matrix $B^{\circ}$ is always quadratic. Elements on the main diagonal are always zero because the transport within a system element is always neglected.

$b_{k k}=0 ; k=1,2, \ldots, n$.

Because the Bloch-Schmigalla triangular method considers only the transport intensity and not its direction, a nonoriented matrix of material flow needs to be created. The nonoriented matrix $B$ is made when all the elements above the main diagonal are summed up with the elements positioned symmetrically beneath the main diagonal.

$B=\left[b_{k j}\right]_{n} ; k, j=1,2, \ldots, n$.

$b_{k j}=b_{k j}^{0}+b_{j k}^{0} \geq 0$.

The second point of this method is the placement of the elements in a triangular mesh. The starting hypothesis of the improved method is that a minimum transport output will be achieved if the first two system elements that are set next to each other, in the triangular mesh, are the elements with the largest material flow between them. If there are more than two elements with the same material flow, then the criterion based on number of connections is applied (if there still exists more than one pair of elements, then a random pair will be selected). The element that has the highest material flow with the first pair is selected next and placed in the triangular network (creating a triangle with the first pair of elements). The element with the highest cumulative material flow between the selected and nonselected workstations is selected next and placed in the triangular mesh next to the pair with which it has the highest material flow. This step is repeated until all the elements are positioned in the triangular mesh. The final stage of the method is the calculation of the goal function by applying equation (2).

One of the major drawbacks of this method is its implementation on a real layout with real distances between the elements. The choice of a potential location is unlimited and the elements can be placed anywhere in a triangular mesh such that they are at unit distances. Unit distances means that the distances between adjacent locations are equal, but the method can be modified with real distances for analyzing an existing layout such as the one presented by Belic et al. [16]. They presented an optimization process of a plant layout used for the production of special transformers using the Bloch-Schmigalla triangular method. Subsequently, they calculated the minimum transport output based on the unit distance of the element and then recalculated the transport output considering real distances between the system elements, and some system limitations. The triangular method is often combined with other methods for a faster and easier technique to find optimal solutions for the layout of the system elements considering the following limitations of the method [17]: it does not consider the workplace; it assumes that the distances between neighboring locations are equal; the cost per transport distance between locations is a constant; and calculations with more than 10 workstations becomes complex and time consuming. There is also a potential possibility of improving the method results by combining the method with software such as visTABLE, which was presented by Banduka et al. [18].

\section{RESULTS AND DISCUSSION}

In a permaculture landscape design, the zone planning method is used to determine the layout of the elements at a location. The location of an element depends on its regularity of use and maintenance.

Mollison [5] determined that a zone arrangement (distances from center) is decided based on two factors: the number of times a human wants to visit a plant, animal, or structure, and the number of times a plant, animal, or structure should be visited by a human. Typically, zones are numbered from 0 to 5 , and can be visualized as a series of concentric circles (Figure 2). 


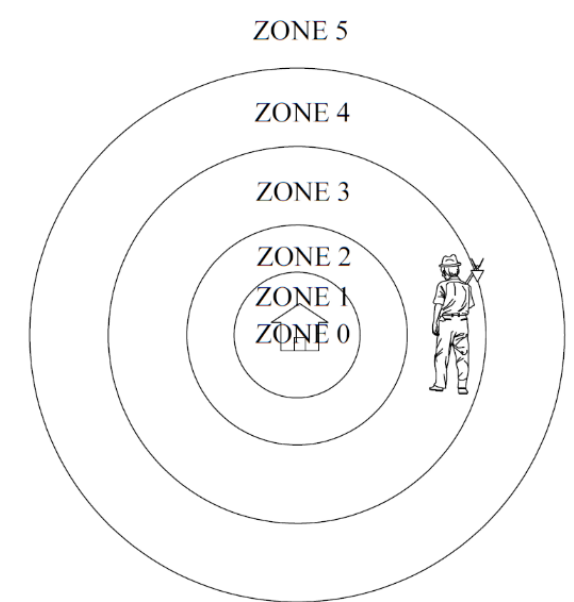

Figure 2 Permaculture zone visualization

Zone 0 is a house or village. This is the place where humans live and spend most of their time. Zone 1 must be nearest to Zone 0 (the house). Elements in Zone 1 require frequent attention. Zone 2 should be closely integrated with Zone 1 and 0 . This zone is visited often (once a day), but does not require as much attention as required by Zone 1 . Zone 3 is the area where the main crops are grown both for domestic use and trade purposes. After establishing the zone elements, care and maintenance required is minimal. Zone 4 is a semi-wild area. This is the area bordering the forest or wilderness, where humans still practice wild gathering, meet the fuel demands of the household, pasture, or range, and plant trees. Zone 5 is a wild area. No human intervention is required. This zone is used for observatory purposes [14].

Table 1 presents the list of elements, number of visits, and representative element for each zone. Because zone borders are not strict (especially for Zone 1 and 2), zone elements can be in different zones for different authors. The most common type of element arrangement is shown in Table 1.

Table 1 Zones and elements

\begin{tabular}{|c|c|c|c|}
\hline Zone & Elements & Times visited (average) & Representative \\
\hline 0 & $\begin{array}{c}\text { House } \\
\text { Annual garden herhs }\end{array}$ & Constantly & House \\
\hline 1 & $\begin{array}{l}\text { and medical plants, } \\
\text { compost bin for } \\
\text { kitchen waste, etc. } \\
\text { Chicken coop, }\end{array}$ & Few times a day & Annual Garden \\
\hline 2 & $\begin{array}{l}\text { beehive, compost, } \\
\text { pigs, milk cows, ducks, } \\
\text { rabbits, etc. }\end{array}$ & Once a day & Chicken coop \\
\hline 3 & $\begin{array}{l}\text { Crops for market } \\
\text { (corn, wheat, etc.), } \\
\text { domestic grain } \\
\text { cultivation }\end{array}$ & Once a week & $\begin{array}{l}\text { Crops for market } \\
\text { (corn) }\end{array}$ \\
\hline 4 & $\begin{array}{l}\text { Grazing animals, nut } \\
\text { trees, oak trees, etc. }\end{array}$ & Once a month & Nut tree \\
\hline 5 & Undisturbed wildness & Only for observation & Undisturbed wildness \\
\hline
\end{tabular}

In the Block-Schmigalla method, a matrix is generated based on material flow. In the material flow analysis, the direction and number of transports per planning period is crucial. In zoning, this number equals the number of times a human wants to go to the zone for using or servicing system elements. Based on representative elements, the number of transports is determined. For a chicken coop, the number of transports was determined by Mollison [5], whereas that for the other zones was approximated or determined based on experience. The material flow is shown in Figure 3. 


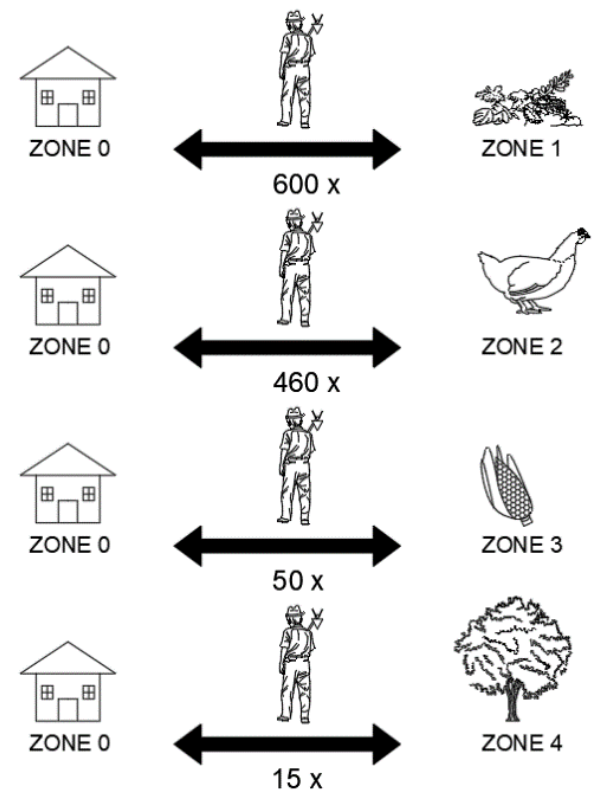

Figure 3 Material flow

Based on the representative element for each zone, a nonoriented matrix of material flow is generated. The matrix and calculation for determining the element position are presented in Table 2. The numbers in the table represent the number of visits per year. The criterion of the original zoning method [5] was based on the number of times a human wants to visit a zone (or system element). Hence, in this first part of the analysis, only the material flow from Zone 0 to the other zones is considered.

Table 2 Material flow matrix and element position calculation

\begin{tabular}{|c|c|c|c|c|c|c|}
\hline From/To & 0 & 1 & 2 & 3 & 4 & 5 \\
\hline 0 & & 600 & 460 & 50 & 15 & \\
\hline \multicolumn{7}{|l|}{1} \\
\hline \multicolumn{7}{|l|}{2} \\
\hline \multicolumn{7}{|l|}{3} \\
\hline \multicolumn{7}{|l|}{4} \\
\hline \multicolumn{7}{|l|}{5} \\
\hline 0 & $\bar{X}$ & & 460 & 50 & 15 & 0 \\
\hline 1 & & $X$ & 0 & 0 & 0 & 0 \\
\hline$\Sigma$ & & & 460 & 50 & 15 & 0 \\
\hline 2 & & & $x$ & 0 & 0 & 0 \\
\hline$\Sigma$ & & & & 50 & 15 & 0 \\
\hline 3 & & & & $X$ & 0 & 0 \\
\hline$\Sigma$ & & & & & 15 & 0 \\
\hline 4 & & & & & $x$ & 0 \\
\hline$\Sigma$ & & & & & & 0 \\
\hline 5 & & & & & & $x$ \\
\hline
\end{tabular}

The next step is to position the elements in a triangular mesh. The first two elements $(0$ and 1$)$ positioned in the mesh will be those with the highest material flow between them. The third element (2), together with the first two, will be placed at the vertices of an equilateral triangle. The fourth element can be placed at any of the vertices adjacent to element 0 (three possible solutions), thereby leaving more than one solution for placing the Babac, S, Belić, D 
fifth element. This problem occurs because the matrix in Table 2 considers only the connections from Zone 0 to the other zones and not from any other zone. Hence, the matrix has data only in the first row. This data is not sufficient to place all the elements in a mesh of equilateral triangles in an acceptable manner.

To solve this problem and include the connections from other zones, a qualitative relation matrix is generated and presented in Table 3 , which considers harmonious relations between components and subsystems.

$A=\left[a_{i j}\right]_{n} ; i, j=1,2, \ldots, n$

where

$a_{i j}=\left\{\begin{array}{l}1 \text { if there is connection between element } i \text { and } j \\ 0 \text { if there is no connection between element } i \text { and } j\end{array}\right.$

Elements on the main diagonal are always zero because an element cannot be connected with itself.

$a_{i i}=0 ; i=1,2, \ldots, n$.

The qualitative relation matrix generation was a deviation from the original method, and this was realized to comply with Mollison's [5] rules for a division of elements between zones; and to gather more data regarding harmonious relations between components and subsystems, which may not be directy related to human impact. The relations between Zone 1 and 2 are that of fertilization, and control of insects and weeds. Chickens forage and turn the soil, which helps to aerate it, and defecate on it, making it more fertile. Chickens also eat insects and weeds, thereby helping to control their numbers. The relation between Zone 2 and 3 is that of spreading manure from Zone 2 (the chicken coop) to Zone 3 (the cornfield). The relation between Zone 3 and 4 is that of a big storage house where the main crops and nuts are stored until they are used or sold. It also stores farming tools and machines required by Zone 3 and 4 , respectively.

Table 3 Qualitative relation matrix

\begin{tabular}{cllllll}
\hline From/To & $\mathbf{0}$ & $\mathbf{1}$ & $\mathbf{2}$ & $\mathbf{3}$ & $\mathbf{4}$ & $\mathbf{5}$ \\
\hline 0 & & 1 & 1 & 1 & 1 & 0 \\
1 & & 1 & 0 & 0 & 0 \\
2 & & & 1 & 0 & 0 \\
3 & & & & 1 & 0 \\
4 & & & & & 0 \\
5 & & & & & \\
\hline
\end{tabular}

Based on the given matrices, a triangular mesh element layout is generated and presented in Figure 4. All elements should be connected to Zone 0; Zone 3 should be near Zone 2; and Zone 4 near Zone 3. Zone 5 is a separate element.

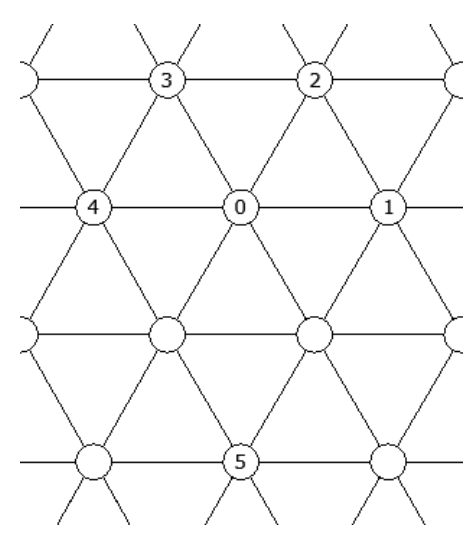

Figure 4 Triangular mesh

Babac, S, Belić, D 


\section{CONCLUSIONS}

This study presented a possible application of an optimization method for permaculture. The methods chosen for comparison were zone planning and the Bloch-Schmigalla triangular method. Based on the material flow analysis between the representative elements (one element represented each zone) and based on the harmonious relations between the elements, the locations of the zones on a triangular mesh were determined. The BlochSchmigalla triangular method was modified by applying a qualitative relation matrix to comply with Mollison's zone division concept. The goal function was not calculated because this study was theoretical. Goal function calculation is more suitable for case studies, where it can provide a feedback to improve the system layout. The method applied is heuristic and as such is similar to the permaculture nature model, where an optimal system model with human interaction is difficult to achieve and measure, but it is a goal permaculture strives to achieve. Models obtained from the Bloch-Schmigalla method often do not fit perfectly on real layouts. Hence, instead of using this method on real farms, some adjustments related to the features of the real landscape (topological and other features) would be required. Based on the limitations and features of the real layouts, and considering the permaculture core tenets and principles, occasionally, the "wedges" of a wilderness zone can even be close to a human habitat. Zone planning method is just one of the methods of permaculture design, and it gives a theoretical layout of the system elements and an in-depth layout design considering other factors such as water availability, wind activity, sun energy, soil quality, etc. For future research, the next logical step will be the analysis of a real permaculture farm considering all relations between the elements (in and between the zones) to create an optimal layout using one of the many mult-agent planning methods to fulfil all the criteria for designing a complete permaculture harmonious system. A qualitative relation matrix, which leads to a deviation from the original Bloch-Schmigalla method, should be considered during the planning of a real permaculture farm because it shows harmonious relations between the system elements, which may or may not be related to human behavior (potentially difficult to measure quantitatively). The determination of real material flow intensities will also be a challenging task because of the varying seasonal requirements for servicing and using different plants, animals, and structures; and differences in caring for plants at different stages of growth, such as sprouted, fully grown, etc. The analysis of a real permaculture farm can be deeper than the one presented in this study, because of deeper insights into the relations (material flows) between locations. However, the determination and quantification of processes within a farm could potentially be complex and time consuming.

\section{References}

[1] Rothe, K. 2014: Permaculture Design: On the Practice of Radical Imagination, Communication $+1,3$ (1), pp.1-18, https://doi.org/10.7275/R58913S2

[2] Holmgen, H. 2002: Permaculture, Principles and Pathways Beyond Sustainability, Holmgren Design Services, Hampshire

[3] Fukuoka, M. 1992: The One-straw Revolution: An Introduction to Natural Farming. Revised edition, Other India Press

[4] Fukuoka, M. 1987: The Natural Way of Farming: The Theory and Practice of Green Philosophy, Japan Publications, Inc., Tokyo and New York

[5] Mollison, B. 1979: Permaculture Two: Practical Design for Town and Country in Permanent Agriculture. 1st ed., Australia: Tagari Publications, Tasmania

[6] Molsblech, C., Sadowsky, V. 2014: A new approach for generating facility layouts using an algorithmic approach, $13^{\text {th }}$ IMHRC Proceedings, Cincinnati, Ohio, USA

[7] Vranješ, B. 1977: Komparacija postojećih numeričkih metoda za optimizaciju rasporeda radnih mjesta, sa gledišta efikasnosti, za slučaj problema s ograničenjima, Institut za proizvodno mašinstvo u Novom Sadu, Novi Sad

[8] Garey, M.R., Johnson, D.S. 1979: Computers and intractability: a guide to the theory of NP-completeness, W.H. Freeman, New York

[9] Driara, A., Pierreval, H., Hajri-Gabouj, S. 2006: Facility layout problems: a literature analysis, IFAC Proceedings Volumes, 39 (3), pp. 389-400, https://doi.org/10.3182/20060517-3-FR-2903.00208 
[10] Kouvelis, P., Kim, M.W. 1992: Unidirectional loop network layout problem in automated manufacturing systems, Operations research, 40 (3), pp. 533-550, https://doi.org/10.1287/opre.40.3.533

[11] Meller, R.D., Narayanan, V., Vance, P.H. 1998: Optimal facility layout design, Operations Research Letters, 23 (3-5), pp. 117-127, https://doi.org/10.1016/S0167-6377(98)00024-8

[12] Kunica, Z. 2016: Projektiranje proizvodnih sustava, Faculty of Mechanical Engineering and Naval Architecture, University of Zagreb, Zagreb

[13] Djassemi, M. 2007: Improving Factory Layout under a Mixed Floor and Overhead Material Handling Condition, Journal of Manufacturing Technology Management, 18 (3), pp. 281-291, https://doi.org/10.1108/17410380710730611

[14] Mollison, B. 2002: Permaculture: A Designers Manual. 2nd ed., Australia: Tagari Publications, Tasmania

[15] Schmigalla, H. 1970: Methoden zur optimalen Maschinenanordnung, VEB Verlag Technik, Berlin (in German)

[16] Belic, D., Kunica, Z., Opetuk, T., Dukic, G. 2018: Optimization of the plant layout in the production of the special transformers - case study, FME Transactions, 46 (2), pp. 285-290, https://doi.org/10.5937/fmet1802285B

[17] Ficko, M., Palcic, I. 2013: Designing a layout using the modified triangle method, and genetic algorithms, International Journal of Simulation Modelling, 12 (4), pp. 237-251, https://doi.org/10.2507/IJSIMM12(4)3.244

[18] Banduka, N., Mladineo, M., Eric, M. 2017: Designing a layout using Schmigalla method combined with software tool VisTABLE, International Journal of Simulation Modelling, 16 (3), pp. 375-385, https://doi.org/10.2507/IJSIMM16(3)1.379

Please cite this article as:

Babac, S.; Belić, D.: Permaculture Zone Planning Using the Triangular Method, Electronic Journal of the Faculty of Civil Engineering Osijek-e-GFOS, 2018, 17, pp. 100-110, https://doi.org/10.13167/2018.17.10 